\title{
The Impact of Characteristics of B2C Retailer on Purchasing Intention-Based on TAM Model
}

\author{
Qinchang Zhu, Ming Lei \\ College of Business Management, South China University of Technology, Guangzhou, China \\ Email:qczhuzhu@163.com
}

How to cite this paper: Zhu, Q.C. and Lei, M. (2016) The Impact of Characteristics of B2C Retailer on Purchasing IntentionBased on TAM Model. Open Journal of Business and Management, 4, 784-798. http://dx.doi.org/10.4236/ojbm.2016.44076

Received: September 6, 2016

Accepted: October 28, 2016

Published: October 31, 2016

Copyright $\odot 2016$ by authors and Scientific Research Publishing Inc. This work is licensed under the Creative Commons Attribution International License (CC BY 4.0).

http://creativecommons.org/licenses/by/4.0/ (c) (i) Open Access

\begin{abstract}
The rapid development of Internet makes B2C E-commerce more and more popular. This paper is based on TAM model and related consumer behavior theory, structuring the hypothesis model of consumer intention. Then we used SPSS 19.0 and Amos 21.0 to analyze data, and to explore the relationship between the characteristics of online retail and consumer perception, and relationship between consumer perception and consumer intention. The results suggest that: 1) credit degree negatively influences perceived risks; 2 ) information quality has a significant positive impact on perceived usefulness and perceived ease of use, and a significant negative impact on perceived risk; 3) service quality has a significant positive impact on perceived usefulness and perceived ease of use, and the impact on the perceived risk is not significant; 4) perceived usefulness and perceived ease of use positively influence purchasing intention, perceived risks negatively influence purchasing intention. The conclusion of this study may be useful for online retailer to make valid marketing strategies.
\end{abstract}

\section{Keywords}

Online Retailing, Perceived Usefulness (PU), Perceived Ease of Use (PEOU), Perceived Risks, Consumer Intention

\section{Introduction}

The number of Chinese internet users and online shopping user has been increasing rapidly. According to the 38th Statistical Report on Internet Development in China released by China Internet Network Information Center (CNNIC) in Beijing [1], as of June 2016, the number of Chinese netizens has reached 710 million, with an increase rate of $3.1 \%$. The scale of mobile phone users has reached 656 million at the same time. Online shopping users have reached 448 million, increase 34.48 million with an increasing rate of $8.3 \%$ comparing to which by the end of 2015. "2015 Annual Chinese 
e-commerce market data monitoring report" shows that China's online retail market transaction scale has reached 3.8285 trillion yuan until 2015, with an increasing rate of $35.7 \%$.

Responding to the daily rising consumer demanding, B2C shopping network like JD, Tianmao, and Weipinhui etc. has gain a great growth. Along with rapid development of various network business models, online shopping has widely infiltrated into all fields of society. As the network environment and law and regulations get better day by day, the scale of online shopping will keep growing. However, to gain and keep more customers, B2C retailers are still facing a series of problems like information quality, service quality, trust and logistics.

Gaining and keeping customers is the key of success of B2C retailer. In consumer behavior research, intention is an important tool of behavior prediction. Planned Behavior Theory noted that behavior is caused by both behavioral intention and perceived behavioral control. Consumer purchase intention refers to the tendency of buying something. Behavioral intention is an extremely important predictor of behavior. Therefore, it is important to analyze and interpret the formation mechanism of purchase intention. B2C business is going gangbusters in online retailing market. "Onestop service" provided by this kind of retailers acquires more consumer recognition. This paper studies consumer intention basing on TAM, which is useful to help us to know more about how to implement marketing in the $\mathrm{B} 2 \mathrm{C}$ field from customers' perspectives.

\section{Variable Definition and Related Discussion}

\subsection{Consumer Intention}

Whether consumers will ultimately buy the selected products depends largely on their purchase intention. Therefore, one should know about consumers' intention first if he/she plans to predict purchase behavior. Intention refers to the subjective probability of doing something. Purchase Intention refers to the possibility of buying a product or service by a consumer, and it is a subjective psychological feeling. Mullet (1985) considered that consumers' attitudes towards a product or brand, coupled with the role of external factors, constitutes consumer's purchase intention [2]. Purchase intention can be viewed as the tendency to buy something and as an important indicator of predicting purchase behaviors. Dodds (1991) defined purchase intention as the probability to buy something, and it was composed by the attitude towards a product or a brand and something external factors [3]. Grewal et al. (1997) pointed out that purchase intention is the possibility of buying a certain product [4].

Blackwell (2001) thought that the willingness to buy means what consumers think they want to buy. Schiffima and Kanuk (2000) pointed out that purchase intention is used to measure the possibility of buying a particular product.

Definitions made by different scholar are not exactly the same, but most of them consistently considered purchase intention as a psychological activity and the possibility of buying something. Therefore, we define purchase intention as the possibility and probability of buying certain products or services in the paper. 


\subsection{TAM}

Theory of Reasonable Action-TRA is a model using to test and explain the behaviors of human being. Davis (1986) constructed Technology Acceptance Model (TAM) on the basis of TRA [5] [6]. The main goal of TAM is to make a tool to predict the adoption of information system. TAM proposed that the behavior of using information system is caused by behavior intention, and intention is caused by both users' attitude towards using system and perceived usefulness of information system. Attitude reflects individual's good or bad feeling of using system, which is determined by both perceived usefulness (PU) and perceived ease of use (PEOU) Perceived usefulness (PU) is affected by both perceived convenience and external factors. Perceived usefulness (PU) refers to individual's feeling about the extent of improving performance by using certain application system. Perceived convenience refers to individual's expectation of the ease extent of using system. The more useful and convenient of using a technique, the more positive of people's attitude and intention towards them and the more possible to adopt them.

Davis et al. put forward advanced TAM. This model divides into two stages, including prior model and later model. They omitted attitude variables in this advanced model. Behavior intention is affected by both perceived usefulness and perceived ease of use when consumers adopt the technology for the first time, and affected only by perceived usefulness. Perceived ease of use has indirect effect on behavior intention through affecting perceived usefulness. That is to say, perceived ease of use has great impact on initial technique adopter but small to old users.

In the aspect of $\mathrm{B} 2 \mathrm{C}$ shopping, perceived ease of use and perceived usefulness affects both shopping attitude and behavior of consumers. For example, interface design, the procedure of placing an order, and payment method, as well as protection to consumers' private information have direct influence on consumers' online shopping intention and behavior. Many scholar adopted TAM to study online shopping.

\subsection{Perceived Risk}

Bauer (1967) put forward perceived risk at the first time [7]. He believes that consumer behavior will cause unpredictable consequences, and some of the consequences are likely to be unhappy. Therefore, consumer behaviors involve risk in this sense. He points out that perceived risks mainly involve uncertainty of decision and seriousness of decision results. Cox (1967) put forward that it may bring out perceived risks when consumer cannot makes sure which kind of product or service can meet their needs or the results cannot meet their expectation after shopping [8]. Cunningham (1967) performed an empirical research and divided the perceived risks into the following two factors: 1) uncertainty, that is, subjective probabilities for a particular consumer about whether something is going to occur; 2) the consequences, that is, the danger of results caused by something [9]. This definition has become the mainstream of the subsequent research about perceived risk, and gets the recognition of most follow-up scholars. In terms of online shopping, Sandra et al. (2003) define perceived risk as "the subjective expectations of loss in an online shopping experience" [10]. 
In terms of the dimension of perceived risks, Woodside (1968) believes that perceived risks can be divided into three aspects: social, functional and economic. Jacoby and Kaplan (1974) divided consumer perceived risk into five aspects: financial risk, functional risk, physical risk, social psychological risk and social risk [11]. Stone and Gronhaug (1993) pointed out that the financial, functional, physical, psychological, social and time risks have $88.8 \%$ interpreting ability of the overall perceived risk [12]. So far, most of the network perceived risks researches used these six dimensions. Miyazaki et al. (2002) studied the impact of perceived risk such as privacy risk and security risk on consumer's online shopping behavior [13]. Dong Dahai et al. (2005) used factor analysis and other statistical techniques to draw the following four dimensions of perceived risks: the core services risks from network retailers, following risks of online shopping, privacy risks and fake risks [14].

Based on previous research, this study defines perceived risks as the subjective expectations of the various consequences brought by shopping on B2C websites.

\subsection{Retailer Literature Review}

\section{1) Service Quality of Network Retailer}

In 2000, Parasuraman et al. defined the quality of electronic services as the extent of how a website can enable customers to efficiently browse, query, and shopping, and how they can distribute products and services conveniently. Zeithaml, Parasuraman, and Malhotra (2002) first proposed the concept of website service quality (E-Service Quality) and defined it as the extent to which a website facilitates efficient and effective shopping, purchasing, and delivery [15]. Santos (2003) defined the quality of electronic services as the overall evaluation and judgment of the extent of excellence of E-service provided by network shopping market [16]. Parasuraman (2005) did an in-depth study of the quality of electronic services and defined it as the extent to which how website facilitates efficient and effective shopping, procurement and delivery [17].

Online retailers refer to the retail business who does commercial activities by means of the Internet. Consumers can not actually come into contact with the goods because network goods are invisible. Therefore, the quality of network services is an important factor that affects the intention of online shopping. (Berry Zeithaml, Leonard, 1998) The key factors of customers' evaluation on service quality are summarized as five, which are tangible, reliability, responsiveness, assurance, and compassion. The subsequent researches of network service quality are basically based on these five elements. By constructing scale, (Zhao Weihong, Xiong Xiaoming, 2015) pointed out that service quality of network retail includes four dimensions: Environmental quality, process quality, result quality and recovery quality [18]. Among them, the environmental quality is composed by the interface accessibility, interface aesthetics, system effectiveness and usefulness of information; process quality is composed by transaction safety, professional service and site response; the result quality is composed by the quality assurance and performance of the shop; and the recovery quality consists of online responsiveness and compensation. Four dimensions could predict customer satisfaction and 
trust, and can further predict customer loyalty. Guo Zhiqing (2014) put forward that service quality of retailer network could be divided into necessary quality, expected quality, attractive quality, and pointed out that Internet retailers could develop and grow in fierce competition only if they keep necessary quality, enhance expected quality, and increase attractive quality [19].

Based on the above research results, this study considers the reliability, convenience, security and other aspects of the service quality of the network retailers.

\section{2) Credit Degree of Retailer}

Many scholars have confirmed that the reputation of online retailers will affect the consumer's trust on the network behavior (McKnight \& Chervan, 1998; Jarvenpaa, Tractinsky \& Vitale, 2000; Koufaris \& Hampton-Sosa, 2004) [20]. Consumers' perception of the reputation of online retailers can be divided into two categories: cognitive appraisals and emotional tendency. The brand and scale of enterprises may affect cognitive appraisals of consumers. And the main factors affecting emotional tendency of consumers are fine reputation and WOM. Weigelt and Camerer (1988) thought that the reputation is a set of characteristics of the company, originating from the past behavior of the enterprise [21]. Wartick (1992) Reputation is individual's feeling about to what extent can organization response meet stakeholders' need. Herbig and Milewicz (1993) believe that the reputation is a whole cognitive judgment of the past behavior of the enterprise [22]. Fombrun (1996 and 2000) believes that corporate reputation is expressed by the emotional reaction to the enterprise from the consumers, investors, employers and the public [23]. Retailer reputation can be an important risk-reducing mechanism in such environments. Assuming that all else is equal, consumers are more likely to buy from an online retailer with better online reputation (Kotha et al., 2001) [24].

We define reputation of online retailer as the degree of consumers' good or bad feeling of online retailer in this paper.

\section{3) Information Quality of Retailer}

Information quality refers to the measurement of information, an output of information system (Delone \& Mclean, 1992) [25]. Information quality of the e-commerce system includes: 1) Completeness; 2) Ease of Understanding; 3) Personalization; 4) Relevance; 5) Security (Delone \& Mclean, 2003) [26]. It is difficult for people to deal with such overloading information these days. Therefore, it is so critical for online retails to provide high quality information that they can provide convenience for consumers to make decisions. Unlike offline retailing, consumers shopping online cannot touch the product, they can only make purchase decisions based on the information provided by the website, such as the display of products, previous evaluation of consumers, and online interaction with the retailers. Janda believed that everything shown by the website, such as the information quality, will affect the consumer's feelings when consumers browse the website. Visual display of the visual elements of the site, such as color, could beautify the overall appearance of the site and enhance the consumer's pleasant experience. This paper evaluates the information quality of retailer mainly from commodity display, real-time interaction and consumer's evaluation. 


\section{Research and Assumptions}

\subsection{Research Model}

In the previous literature reviews, TAM has been used by many scholars to study the influence factors of consumer behavior in electronic commerce, and some scholars made some improvements of the TAM in the light of the actual needs of the research. Therefore, this study also takes the TAM as the basic framework. We carry on certain modifications and supplements of this model with the actual situation of network consumption, and put forward the following model. As shown in the following picture, the independent variables are the three major characteristics of online retailers: credibility, information quality and service quality; the middle variables are three consumer perception: perceived usefulness (PU); perceived ease of use (PEOU) and perceived risks; the dependent variables is consuming intention. The relationship between various variables of the model is shown with the arrow in Figure 1.

\subsection{Research Hypothesis}

\section{1) Characteristics of Online Retailers and Perceived Usefulness}

According to the definition of perceived usefulness by Davis (1989), we define perceived usefulness as the degree of consumers' belief of how online shopping will improve the efficiency of shopping or save cost [5]. The most prominent advantage of network retailing is its convenience and speed. You can get your favorite products with only some clicks. However, due to the overloading online information, it is difficult to distinguish information that can provide a basis for their decision making. People need to spend a lot of time to collect information before making shopping decisions. Retailers' reputation will affect the consumer's perception of the product information. Mudambi and Schuff (2010) used the theory of information economics to analyze online

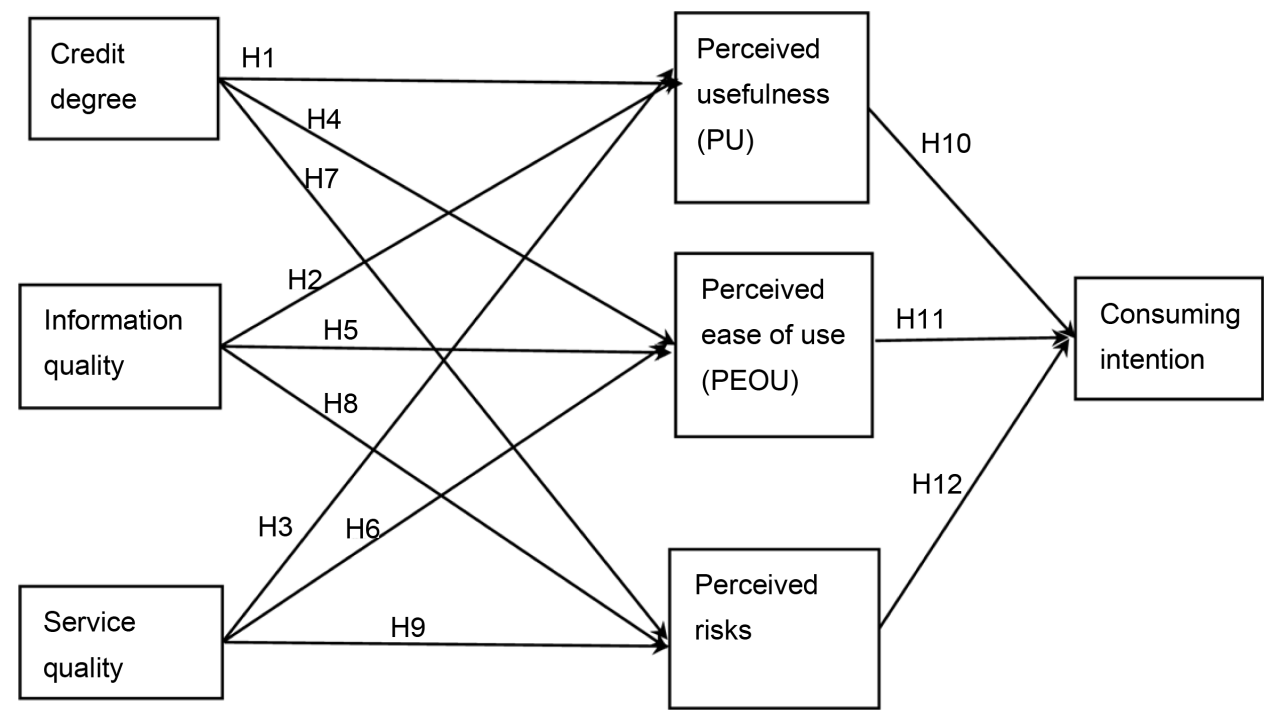

Figure 1. The influencing factors model of network consumption intention under B2C environment. 
product reviews, and thought that the depth of reviews can improve the diagnostic power of information [27]. When consumers have a positive or negative attitude to some products, but still not decide to buy or give up them, high quality WOM can help consumers classify them. Therefore, consumers can improve the efficiency of purchasing and reduce transaction time and energy cost. Huang and Tsang (2011) analyzed the factors that arouse the ripple effect of WOM from the perspective of e-WOM communication, and pointed out the main factor is perceived quality of information, which has a significant positive correlation with information reception [28]. In ELM model, Petty and Cacioppo (1993) put forward that information quality is an important factor to determine the persuasive power [29]. Saeed et al. (2003) also considers that service quality has impact on perceived usefulness [30].

In conclusion, we put forward the following hypothesis:

(H1): Credit degree of online retailers is positively associated with the perceived usefulness of consumers.

(H2): Information quality of online retailers is positively associated with the perceived usefulness of consumers.

(H3): Service quality of online retailers is positively associated with the perceived usefulness of consumers.

\section{2) Characteristics of Online Retailers and Perceived Ease of Use (PEOU)}

Perceived ease of use is defined as the ease degree to which consumers believe the use of this technology (Davis, 1989) [5]. It can be defined as the ease degree with which the consumer considers the operation in the transaction process under network transactions in the $\mathrm{B} 2 \mathrm{C}$ environment. Online retailers must ensure consumers to get desired information conveniently and fast, on the premise of providing useful information. Moreover, they need to provide consulting services in a smooth and quick way. From the daily shopping experience, we can know that high quality information and high quality service contribute greatly to convenient and fast online shopping, and also help consumers solve their problems. Therefore, the perceived ease of use of online shopping is higher. At the same time, retailers with high credit degree can enhance the sense of trust of consumers. Consumers with higher perceived ease of use are more likely to buy.

In conclusion, we put forward the following hypothesis:

(H4): Credit degree of online retailers is positively associated with perceived ease of use of consumers.

(H5): Information quality of online retailers is positively associated with perceived ease of use of consumers.

(H6): Service quality of online retailers is positively associated with perceived ease of use of consumers.

\section{3) Characteristics of Online Retailers and Perceived Risks}

Mitchell (1999) believes that consumers tend to reduce their perceived risk rather than maximize their perceived value when making purchase decisions [31]. By empirical studies, Pavlou (2003) confirmed that perceived risks have negative impacts on con- 
sumer shopping intention [32]. Ganeson and Shankar (1994) found that the retailer's reputation is very important in the study of the factors influencing the perceived risks of the retailers. Consumers generally believe that a reputable online retailer can reduce the negative impact caused by the high risk levels contained in the network. The higher service quality the retailers provide, the more likely that consumers feel that the retailer can reduce perceived risks. Many empirical studies suggest that there is a negative correlation between service quality and customer perceived risk.

In conclusion, we put forward the following hypothesis:

(H7): Credit degree of online retailers is negatively associated with perceived risk of consumers.

(H8): Information quality of online retailers is negatively associated with perceived risk of consumers.

(H9): Service quality of online retailers is negatively associated with perceived risk of consumers.

\section{4) Perceptions of Consumers and Purchasing Intention}

Research shows that if the users feel that they just need relatively little cognitive effort in the process of interacting with the technology, they will be more likely to interact with the technology. Davis put forward that perceived usefulness is the predictors of using behavior when he proposed TAM. Many subsequent studies have found that users' acceptance of information technology is largely driven by perceived usefulness (Davis et al. 1989; Adams et al., 1992; Szajna, 1996; Venkatesh \& Davis, 2000) [5] [33]. Studies have proved that perceived usefulness is an important factor to predict the acceptance of e-commerce model, and it has significant influence on the attitude, intention and behavior about using e-commerce (Gefen \& Straub, 2000; Feathennan \& Pavlou, 2003) [32] [34]. In the study of online shopping intention, Thompson (2003) found that perceived risk will lead to consumers' negative assessment on the transaction. The more positive the overall assessment of the transaction is, the greater the willingness of online shopping is. Sandra (2003) believed that perceived risk had direct negative effects on the purchase attitude and purchase intention. Nadia (2004) qualitatively studied the relationship between perceived risks and trust level by E-mail interviews. The perceived risks will reduce the level of trust, and also obscure benefits of network shopping reduces the consumer's income. Finally, it lowers consumers' interests.

In conclusion, we put forward the following hypothesis:

(H10): Perceived usefulness of consumers is positively associated with purchase intention.

(H11): Perceived ease of use of consumers is positively associated with purchase intention.

(H12): Perceived risks are negatively associated with purchase intention.

\section{Method and Results}

\subsection{Research Design and Sample Description}

Data for this study were collected as part of a larger mail survey of consumer percep- 
tions about Internet shopping. The questionnaire includes two parts. The first part is about basic information, such as gender, grade, education background and so on. The second part investigates 7 factors of the model with a total of 28 items. We created the scale by referring to the related measurement of variables in this study, and then adjusting it to this study. The scales are composed of 4 items of credit degree referring to the scale of (LeBlanc and Nguyen, 2001) [35]; 4 items of information quality referring to (Chae M., Kim J., et al. 2005); 7 items of service quality referring to Zeithaml (2000) and Parasuramanl (2005); 3 items of perceived usefulness referring to L.R. Vijayasarathy (2004); 3 items of perceived ease of use referring to L.R. Vijayasarathy (2004); 4 items of perceived risks referring to Jacoby and Kaplan (1974) [11]; 3 items of purchasing intention referring to L.R. Vijayasarathy (2004) [36]. Consumers were investigated by filling out Likert seven-point scale (Please indicate the extent to which you agree with each of the following statements by using the following scale: $1=$ strongly disagree, $2=$ disagree, $3=$ slightly disagree, $4=$ neutral, $5=$ slightly agree, $6=$ agree, $7=$ strongly agree).

This study is based on the TAM, and examines the influence of retailer characteristics on the purchasing intention of consumers. Participants were mostly adults working or residing in Zhujiang New Town, a CBD with a population of about 300,000. Questionnaire release time was from July 1, 2016 to July 22, 2016. We collected 322 questionnaires, and we finally acquired 275 after deleting the invalid questionnaires, the valid rate of questionnaires is $85.4 \%$. In recovered samples, men accounted for 59\%; women accounted for $41 \%$. Those whose age between 21 to 25 years old and 26 to 30 years old accounted for $37.9 \%$ and $37.4 \%$ separately. The population of those who searches the Internet 3 - 5 hours every day is 73 , accounting for $26.7 \%$; 5 hours and above 106 people, accounting for $38.5 \%$. It suggested that the investigated group has relatively high network familiarity. The population of those who have shopped over ten times last year accounts for $84.1 \%$, and who spent more than 2000 online shopping in the past year accounted for $69.7 \%$.

\subsection{Reliability and Validity Test}

Reliability refers to consistency, stability and reliability of the test results, that is, the extent to which the consistency of the results if we do repeated test. Scholars commonly use Cronbach's $\alpha$ to test reliability, internal consistency. Generally, we think that the reliability is high if Cronbach's $\alpha$ value is higher than 0.7. As shown in Table 1, The Cronbach's $\alpha$ value of all variables are above 0.7 , which shows that the scale has good reliability.

We created the scale in this study by referring to mature scale in related literature, and we modified the scale according to the results of experts and case interviews, as well as the characteristics of this study and research objects. Therefore, this scale has a good content validity. From Table 1, we can see that the factor loadings of every item of all variables is greater than 0.6 , combined reliability $(\mathrm{CR})$ values are more than 0.7 , all the average variation extraction (AVE) are more than 0.5. All the above indicators showed that the measurement scale had good convergent validity. AVE value of credit 
Table 1. Reliability and validity of all variables.

\begin{tabular}{|c|c|c|c|}
\hline Variables & Scale Items & Factor Loadings & Cronbach's $\alpha$, AVE, CR \\
\hline \multirow{4}{*}{$\begin{array}{l}\text { Credit } \\
\text { Degree }\end{array}$} & CD1: Credibility of the mall I choose is relatively high. & $0.859^{* * *}$ & \multirow[b]{2}{*}{$\begin{array}{l}\text { Cronbach's } \\
\alpha=0.865\end{array}$} \\
\hline & CD2: The reputation of the mall is high. & $0.884^{* * *}$ & \\
\hline & CD3: Online consumers' evaluations on the mall is positive. & $0.839^{* * *}$ & $\mathrm{AVE}=0.712$ \\
\hline & CD4: The mall has proven ability and its scale is gigantic. & $0.791^{\star * *}$ & $\mathrm{CR}=0.908$ \\
\hline \multirow{4}{*}{$\begin{array}{l}\text { Information } \\
\text { Quality }\end{array}$} & IQ1: The website provides consumer's evaluation of the products as a reference. & $0.828^{\star * *}$ & \multirow{4}{*}{$\begin{array}{c}\text { Cronbach's } \\
\alpha=0.877 \\
\mathrm{AVE}=0.733 \\
\mathrm{CR}=0.916\end{array}$} \\
\hline & IQ2: It is convenient to search for products in this website. & $0.856^{* * *}$ & \\
\hline & IQ3: There are displayed pictures and detailed product introductions in this website. & $0.860^{* * *}$ & \\
\hline & $\begin{array}{l}\text { IQ4: The website provided real-time consultation for consumers thorough instant } \\
\text { chat tools or web chat. }\end{array}$ & $0.878^{\star * *}$ & \\
\hline \multirow{7}{*}{$\begin{array}{l}\text { Service } \\
\text { Quality }\end{array}$} & SQ1: The after-sales service policy of the mall is very reasonable. & $0.699^{* * *}$ & \multirow{7}{*}{$\begin{array}{c}\text { Cronbach's } \\
\alpha=0.901 \\
\mathrm{AVE}=0.629 \\
\mathrm{CR}=0.922\end{array}$} \\
\hline & SQ2: The delivery of the products is very efficient. & $0.756^{\star * *}$ & \\
\hline & SQ3: The mall supports various payment way. & $0.723^{* * *}$ & \\
\hline & SQ4:The mall provide service in professional way. & $0.852^{* * *}$ & \\
\hline & SQ5: Customer services provide timely service. & $0.855^{* * *}$ & \\
\hline & SQ6: Website customer service make a quick response on your request. & $0.832^{* * *}$ & \\
\hline & SQ7: This website is very reliable. & $0.820^{\star * *}$ & \\
\hline \multirow{3}{*}{$\begin{array}{l}\text { Perceived } \\
\text { Usefulness }\end{array}$} & PU1: The Internet enables (will enable) me to complete shopping quickly & $0.759^{* * *}$ & \multirow{2}{*}{$\begin{array}{c}\text { Cronbach's } \\
\alpha=0.710 \\
\text { AVE }=0.638\end{array}$} \\
\hline & PU2: The Internet makes (will make) it easy to do comparison shopping. & $0.775^{\star * *}$ & \\
\hline & PU3: The Internet gives (will give) me access to useful shopping information. & $0.859^{* * *}$ & $\mathrm{CR}=0.841$ \\
\hline \multirow{3}{*}{$\begin{array}{c}\text { Perceived } \\
\text { Ease } \\
\text { of Use }\end{array}$} & PEOU1: Learning to use the Internet for shopping was (would be) easy for me. & $0.791^{* * *}$ & \multirow{3}{*}{$\begin{array}{c}\text { Cronbach's } \\
\alpha=0.780 \\
\mathrm{AVE}=0.697 \\
\mathrm{CR}=0.873\end{array}$} \\
\hline & PEOU2: I believe that Internet shopping is (will be) cumbersome. & $0.877^{\star * *}$ & \\
\hline & PEOU3: Using the Internet for shopping is (will be) frustrating. & $0.834^{* * *}$ & \\
\hline \multirow{4}{*}{$\begin{array}{l}\text { Perceived } \\
\text { Risks }\end{array}$} & PR1: Making online payment in this website is insecure. & $0.678^{* * *}$ & \multirow{4}{*}{$\begin{array}{c}\text { Cronbach's } \\
\alpha=0.742 \\
\mathrm{AVE}=0.567 \\
\mathrm{CR}=0.839\end{array}$} \\
\hline & PR2: Internet retailers cannot be trusted to safeguard my privacy. & $0.770^{* * *}$ & \\
\hline & PR3: The products in delivery may be damaged. & $0.832^{* * *}$ & \\
\hline & PR4: I may purchase fake in this website. & $0.723^{* * *}$ & \\
\hline \multirow{3}{*}{$\begin{array}{l}\text { Purchasing } \\
\text { Intent }\end{array}$} & PI1: I use (intend to use) the Internet frequently to do my shopping. & $0.864^{* * *}$ & \multirow{3}{*}{$\begin{array}{c}\text { Cronbach's } \\
\alpha=0.784 \\
\mathrm{AVE}=0.710 \\
\mathrm{CR}=0.880\end{array}$} \\
\hline & PI2: I use (intend to use) the Internet whenever appropriate to do my shopping. & $0.852^{\star * *}$ & \\
\hline & $\begin{array}{l}\text { PI3: Please indicate the probability that you will shop using the Internet in the near } \\
\text { future. (Anchored by } 1 \text { - very improbable and 7-very probable) }\end{array}$ & $0.811^{\star * *}$ & \\
\hline
\end{tabular}

Note: ${ }^{* * *}$ means $\mathrm{p}<0.001$.

degree, information quality, service quality, perceived usefulness, perceived ease of use, perceived risk, purchasing intention was $0.733,0.629,0.638,0.697,0.712,0.567,0.710$ respectively. From Table 2, we can see that square roots of the AVE values of all the variables are greater than the correlation coefficient between those variables and other variables, so the discriminant validity of the variables is good. 


\subsection{Structure Model and Path Test}

We used Amos 21.0 to analyze 3.3 structure model and relationship between variables in this study. In this model, absolute fitness index are as follows: $\chi^{2}=637.675, \mathrm{df}=335$, GFI $(0.813)>0.80$, CFI $(0.896)>0.80$, RMR $(0.063)<0.08$, RMSEA $(0.068)<0.08$, all of which are acceptable. Reduced fitness index includes PNFI (0.714) and PCFI (0.794), both of which are above 0.5 and are acceptable. IFI (0.897), RFI (0.802) and NFI (0.815) are above $0.80 . \chi^{2} / \mathrm{df}(1.904)<3$. These data indicate that the structural model of this study has good fitness.

As the path coefficient and the significance of hypothesis test shown in Table 3, we can know that all hypotheses except H1, H4 are proved: 1) credit degree negatively influence

Table 2. Correlation coefficient table matrix between variables.

\begin{tabular}{|c|c|c|c|c|c|c|c|}
\hline Variables & $\begin{array}{l}\text { 1) Perceive } \\
\text { usefulness }\end{array}$ & $\begin{array}{l}\text { 2) Perceived } \\
\text { ease of use }\end{array}$ & $\begin{array}{l}\text { 3) Perceived } \\
\text { risks }\end{array}$ & $\begin{array}{l}\text { 4) Credit } \\
\text { degree }\end{array}$ & $\begin{array}{l}\text { 5) Information } \\
\text { quality }\end{array}$ & $\begin{array}{l}\text { 6) Service } \\
\text { quality }\end{array}$ & $\begin{array}{l}\text { 7) Purchasing } \\
\text { intention }\end{array}$ \\
\hline 1 & 0.799 & & & & & & \\
\hline 2 & $-0.216^{\star *}$ & 0.835 & & & & & \\
\hline 3 & $0.565^{\star *}$ & $-0.288^{\star *}$ & 0.753 & & & & \\
\hline 4 & $0.415^{\star *}$ & $0.498^{\star *}$ & $-0.319^{* *}$ & 0.844 & & & \\
\hline 5 & $0.461^{\star *}$ & $0.616^{\star *}$ & $-0.391^{\star *}$ & $0.704^{\star *}$ & 0.856 & & \\
\hline 6 & $0.356^{* *}$ & $0.416^{* *}$ & $-0.218^{\star *}$ & $0.562^{\star \star}$ & $0.506^{\star *}$ & 0.793 & \\
\hline 7 & $0.525^{\star *}$ & $0.596^{* *}$ & $-0.307^{\star *}$ & $0.444^{\star *}$ & $0.595^{\star *}$ & $0.417^{\star *}$ & 0.843 \\
\hline
\end{tabular}

Note: ${ }^{\star}$ represents $\mathrm{p}<0.05 ;{ }^{*}$ represents $\mathrm{p}<0.01 ;{ }^{* *}$ represents $\mathrm{p}<0.001$; the values of the diagonal are the square root of the AVE.

Table 3. Path coefficients and hypothesis verification of theoretical model.

\begin{tabular}{cccccc}
\hline Order & Relationship between variables & $\begin{array}{c}\text { Path } \\
\text { coefficient }\end{array}$ & p value & $\begin{array}{c}\text { Corresponding } \\
\text { hypothesis }\end{array}$ & Test results \\
\hline 1 & Credit degree $\rightarrow$ Perceived usefulness & -0.087 & 0.590 & H1 & Not support \\
2 & Credit degree $\rightarrow$ Perceived ease of use & -0.122 & 0.376 & H4 & Not support \\
3 & Credit degree $\rightarrow$ Perceived risks & $-0.294^{*}$ & 0.031 & H7 & Support \\
4 & Information quality $\rightarrow$ Perceived usefulness & $0.499^{* * *}$ & 0.000 & H2 & Support \\
5 & Information quality $\rightarrow$ Perceived ease of use & $0.652^{* * *}$ & 0.000 & H5 & Support \\
6 & Information quality $\rightarrow$ Perceived risks & $-0.305^{* *}$ & 0.005 & H8 & Support \\
7 & Service quality $\rightarrow$ Perceived usefulness & $0.389^{*}$ & 0.020 & H3 & Support \\
8 & Service quality $\rightarrow$ Perceived ease of use & $0.556^{* *}$ & 0.008 & H6 & Support \\
9 & Service quality $\rightarrow$ Perceived risks & $-0.314^{* *}$ & 0.003 & H9 & Support \\
10 & Perceived usefulness $\rightarrow$ Purchasing intention & $0.349^{* * *}$ & 0.000 & H10 & Support \\
11 & Perceived ease of use $\rightarrow$ Purchasing intention & $0.582^{* * *}$ & 0.000 & H11 & Support \\
12 & Perceived risks $\rightarrow$ Purchasing intention & $-0.201^{*}$ & 0.035 & H12 & Support \\
\hline
\end{tabular}

Note: Path coefficient standardized regression weights; ${ }^{*}$ means $\mathrm{p}<0.05 ;{ }^{* *}$ means $\mathrm{p}<0.01{ }^{* * *}$ means $\mathrm{p}<0.001$. 
perceived risks $(\mathrm{p}<0.05) ; 2)$ information quality has a significant positive impact on perceived usefulness $(\mathrm{p}<0.001)$ and perceived ease of use $(\mathrm{p}<0.001)$, and a significant negative impact on perceived risk ( $\mathrm{p}=0.005<0.05)$; 3 ) service quality has a significant positive impact on perceived usefulness $(\mathrm{p}<0.05)$ and perceived ease of use $(\mathrm{p}<0.01)$, and the impact on the perceived risk is not significant $(\mathrm{p}<0.01)$; 4$)$ perceived usefulness $(\mathrm{p}<0.001)$ and perceived ease of use $(\mathrm{p}<0.001)$ positively influence purchasing intention, perceived risks $(\mathrm{p}<0.05)$ negatively influence purchasing intention.

\section{Discussion and Conclusion}

Basing on TAM, we construct the model of how characteristics of online retailers impact on customer purchasing intention. The results show that the information quality and service quality have positive effect on perceived usefulness and perceived ease of use, that is, the higher the quality of information supplied by retailers is, or the higher perceived service quality is, the more usefulness and ease of use consumer perceive. The credit, information quality, and service quality are all negatively impact on perceived risk, that is, the higher the credibility of the retailer, the higher the quality of information provided and the higher the quality service, the lower the risk consumers feel. Credit degree has no significant influence on perceived usefulness and perceived ease of use. Generally speaking, credit degree of online retailers may have impact on consumer choices. However, through the analysis of model data, we found this effect is not reflected in the improvement of purchasing performance. A high credit degree of the network retailers can only mean that their business activities are more formal, and they provide guaranteed products, but does not mean that there is a price advantage or the purchasing efficiency is higher. Furthermore, the evaluation of online consumers on the products may affect the initial impression on online retailers, but consumers do not necessarily be familiar with the shopping website by other consumers' evaluation. Perceived ease of use is mainly affected by skill level of computer use and the experience of network shopping. Perceived usefulness and perceived ease of use positively influence on consumer purchasing intention, but perceived risks negatively influence purchasing intention, that is, the more the provided efficiency and convenience are, the higher the purchase intention is. When perceived risks are lower, the purchase intention is relative higher.

In this paper, we studied the perception of network consumers by dividing it into three aspects: perceived usefulness, perceived ease of use and perceived risks. It is proved that credit degree, information quality and service quality have influence on consumer's three kinds of perception. We enrich the previous theoretical research on the consumers' intention of online shopping. Davis (1986) puts forward TAM (Technology Acceptance Model), which is mainly used to predict the adoption of information systems, that is, how perceived usefulness and perceived ease of use influence on the information system. This paper confirmed that this division can also be used to predict the online shopping intention of consumers. And, on this basis, we added a new variable of perceived risks to construct an updated model to study the network consumer's purchasing intention. 
Today, online shopping is increasingly popular and consumers can buy almost everything on the Internet. Improving the credit degree, information quality and service quality of enterprises can effectively improve the consumers' purchasing efficiency and convenience, and reduce consumers' perceived risk. High perceived ease of use and perceived usefulness is the key to improve the online shopping intention. This paper has practical significance for the construction of a retailing shopping site.

Firstly, online retailers should focus on the information display of products. They need to make corresponding display scheme according to different kinds of products. They also need to make efforts to lay consumer's doubts. For those giant retailers, they can also try to use innovative display method or purchase innovative and efficient shopping assisted technology. For example, consumers buying the clothing on the Internet worry most about whether clothes fit, so if there is an excellent solution for this problem, they can easily develop the online clothing market.

Secondly, online retailers should provide good service quality in the whole shopping process. They need to train their employees to be professional so consumers can have a wonderful experience whether in pre-consulting or during the searching or checkout. There is no significant price difference between different online retailers in the competitive online shopping market. Therefore, online retailers need to differentiate their service if they want to develop and grow.

Limitations to this study are in the areas of sampling and external factors. Firstly, the participants of this study are mainly B2C online shoppers. We do not include other online shopping way. Therefore, whether the conclusions can be extended to other network shopping way, such as $\mathrm{C} 2 \mathrm{C}$, has yet to be further studied. Secondly, we only consider three antecedents of consumer perception, namely the retailer's credit degree, information quality, service quality, but not include external factors. In fact, other external factors such as the popularity of online shopping, novelty, etc. may also affect consumer perception, and these external factors can be taken into account in future studies.

\section{Acknowledgements}

The authors would like to thank the Editor and anonymous referees for their helpful comments and suggestion.

\section{References}

[1] CNNIC (2016) 38th China Internet Development Statistics Report. China Internet Network Information Center. http://www.cnnic.cn/hlwfzyj/hlwxzbg/hlwtjbg/201608/t20160803_54392.htm

[2] Mullet, G.M. and Karson, M.J. (1985) Analysis of Purchase Intent Scales Weighted by Probability of Actual Purchase. Journal of Marketing Research, 22, 93-96. http://dx.doi.org/10.2307/3151555

[3] Dodds, W.B. (1991) In Search of Value: How Price and Store Name Information Influence Buyers' Product Perceptions. Journal of Services Marketing, 5, 27-36. http://dx.doi.org/10.1108/07363769110034974 
[4] Kavanoor, S., Grewal, D. and Blodgett, J. (1997) Ads Promoting OTC Medications: The Effect of Ad Format and Credibility on Beliefs, Attitudes, and Purchase Intentions. Journal of Business Research, 40, 219-227. http://dx.doi.org/10.1016/S0148-2963(96)00238-X

[5] Davis, F.D. (1989) Perceived Usefulness, Perceived Ease of Use, and User Acceptance of Information Technology. MIS Quarterly, 13, 319-340. http://dx.doi.org/10.2307/249008

[6] Venkatesh, V. and Davis, F.D. (2000) A Theoretical Extension of the Technology Acceptance Model: Four Longitudinal Field Studies. Management Science, 46, 186-204. http://dx.doi.org/10.1287/mnsc.46.2.186.11926

[7] Bauer, R.A. (1967) Consumer Behavior as Risk Taking. In: Cox, D.F., Ed., Risk Taking \& Information Handling in Consumer Behavior, Graduate School of Business Administration, Harvard University, Boston, 23-33

[8] Cox, D.F. (1967) Risk Taking and Information Handling in Consume Behavior. 6, No. 1.

[9] Cunningham, S.M. (1967) The Major Dimensions of Perceived Risk. In: Cox, D.F., Ed., Risk Taking and Information Handling in Consumer Behavior, Harvard University Press, Boston, MA.

[10] Forsythe, S.M. and Shi, B. (2003) Consumer Patronage and Risk Perceptions in Internet Shopping. Journal of Business Research, 56, 867-875. http://dx.doi.org/10.1016/S0148-2963(01)00273-9

[11] Kaplan, L.B., Szybillo, G.J. and Jacoby, J. (1974) Components of Perceived Risk in Product Purchase: A Cross-Validation. Journal of Applied Psychology, 59, 287-291. http://dx.doi.org/10.1037/h0036657

[12] Stone, R. and Gronhaug, K. (1993) Perceived Risk: Further Considerations for the Marketing Discipline. European Journal of Marketing, 27, 39-50. http://dx.doi.org/10.1108/03090569310026637

[13] Miyazaki, A.D. and Krishnamurthy, S. (2002) Internet Seals of Approval: Effects on Online Privacy Policies and Consumer Perceptions. Journal of Consumer Affairs, 36, 28-49. http://dx.doi.org/10.1111/j.1745-6606.2002.tb00419.x

[14] Dong, D.H., et al. (2005) Study on the Structure of Perceived Risk of Consumers' Online Shopping. Chinese Journal of Management, 2, 55-60. http://glxb.hust.edu.cn/CN/article/showZhaiYao.do?id=9266

[15] Zeithaml, V.A., Parasuraman, A. and Malhotra, A. (2002) Service Quality Delivery through Web Sites: A Critical Review of Extant Knowledge. Journal of the Academy of Marketing Science, 30, 362-375. http://dx.doi.org/10.1177/009207002236911

[16] Santos, J. (2003) E-Service Quality: A Model of Virtual Service Quality Dimensions. Managing Service Quality, 13, 233-246. http://dx.doi.org/10.1108/09604520310476490

[17] Parasuraman, A., Zeithaml, V.A. and Malhotra, A. (2005) E-S-Qual: A Multiple-Item Scale for Assessing Electronic Service Quality. Journal of Service Research, 7, 213-233. http://dx.doi.org/10.1177/1094670504271156

[18] Zhao, W.H. and Xiong, X.M. (2015) Measurement and Management of Online Retail Service Quality-Based on Chinese Context. Business Review, 27, 120-130. http://www.glplzz.com/CN/abstract/abstract382.shtml

[19] Guo, Z.Q. (2014) Evaluation of Service Quality of Online Retailers Based on KANO Model. Business Economy, No. 18, 38-40.

[20] Hampton-Sosa, W. and Koufaris, M. (2005) The Effect of Web Site Perceptions on Initial Trust in the Owner Company. International Journal of Electronic Commerce, 10, 55-81.

[21] Weigelt, K. and Camerer, C. (1988) Reputation and Corporate Strategy: A Review of Recent Theory and Applications. Strategic Management Journal, 9, 443-454. 
http://dx.doi.org/10.1002/smj.4250090505

[22] Herbig, P. and Milewicz, J. (1993) The Relationship of Reputation and Credibility to Brand Success. Journal of Consumer Marketing, 10, 18-24. http://dx.doi.org/10.1108/EUM0000000002601

[23] Fombrun, C.J. (1996) Reputation: Realizing Value from the Corporate Image. Harvard Business School Press, Harvard.

[24] Kotha, S., Rajgopal, S. and Rindova, V. (2001) Reputation Building and Performance: An Empirical Analysis of the Top-50 Pure Internet Firms. European Management Journal, 19, 571-586. http://dx.doi.org/10.1016/S0263-2373(01)00083-4

[25] Delone, W.H. and Mclean, E.R. (1992) Information Systems Success: The Quest for the Dependent Variable. Information Systems Research, 3, 60-95.

http://dx.doi.org/10.1287/isre.3.1.60

[26] Delone, W.H. and Mclean, E.R. (2003) The Delone and Mclean Model of Information System Success: A Ten-Year Update. Journal of Management Information Systems, 19, 9-30.

[27] Mudambi, S.M. and Schuff, D. (2010) What Makes a Helpful Online Review? A Study of Customer Reviews on Amazon. Com. MIS Quarterly, 34, 185-200.

[28] Huang, M., Cai, F., Tsang, A.S.L. and Zhou, N. (2011) Making Your Online Voice Loud: The Critical Role of WOM Information. European Journal of Marketing, 45, 1277-1297.

http://dx.doi.org/10.1108/03090561111137714

[29] Petty, R.E., Wegener, D.T., Fabrigar, L.R., Priester, J.R. and Cacioppo, J.T. (1993) Conceptual and Methodological Issues in the Elaboration Likelihood Model of Persuasion: A Reply to the Michigan State Critics. Communication Theory, 3, 336-342. http://dx.doi.org/10.1111/j.1468-2885.1993.tb00078.x

[30] Choudhary, A.I., Saeed, S., Humayon, A.A. and Humyon, A.A. (2015) Service Quality Factors Affecting Adoption of Internet Banking In Pakistan. International Journal of Economics, Commerce and Management, 3, 1-10.

[31] Mitchell, V. (1999) Consumer Perceived Risk: Conceptualisations and Models. European Journal of Marketing, 33, 163-195. http://dx.doi.org/10.1108/03090569910249229

[32] Featherman, M.S. and Pavlou, P.A. (2003) Predicting E-Services Adoption: A Perceived Risk Facets Perspective. International Journal of Human-Computer Studies, 59, 451-474. http://dx.doi.org/10.1016/S1071-5819(03)00111-3

[33] Szajna, B. (1996) Empirical Evaluation of the Revised Technology Acceptance Model. Management Science, 42, 85-92. http://dx.doi.org/10.1287/mnsc.42.1.85

[34] Gefen, D., Straub, D. and Boudreau, M. (2000) Structural Equation Modeling and Regression: Guidelines for Research Practice. Communications of the Association of Information Systems, 4, Article 7.

[35] Nguyen, N. and Leblanc, G. (2001) Corporate Image and Corporate Reputation in Customers' Retention Decisions in Services. Journal of Retailing \& Consumer Services, 8, 227 236. http://dx.doi.org/10.1016/S0969-6989(00)00029-1

[36] Vijayasarathy, L.R. (2004) Predicting Consumer Intentions to Use On-Line Shopping: The Case for an Augmented Technology Acceptance Model. Information \& Management, 41, 747-762. http://dx.doi.org/10.1016/j.im.2003.08.011 
Submit or recommend next manuscript to SCIRP and we will provide best service for you:

Accepting pre-submission inquiries through Email, Facebook, LinkedIn, Twitter, etc. A wide selection of journals (inclusive of 9 subjects, more than 200 journals)

Providing 24-hour high-quality service

User-friendly online submission system

Fair and swift peer-review system

Efficient typesetting and proofreading procedure

Display of the result of downloads and visits, as well as the number of cited articles

Maximum dissemination of your research work

Submit your manuscript at: http://papersubmission.scirp.org/

Or contact ojbm@scirp.org 